\title{
SEASONAL VARIATION IN HAEMATOLOGICAL PARAMETERS IN CROSSBRED HORSES USED FOR URBAN TRACTION FROM LAGES, SC, BRAZIL
}

(Variações sazonais dos parâmetros hematológicos de equinos mestiços usados para tração urbana em Lages, SC, Brasil)

\author{
Anderson Fernando de Souza ${ }^{1 *}$, Jonas Signor ${ }^{1}$, Jackson Schade ${ }^{1}$, Mere Erika Saito ${ }^{1}$, Thiago Rinaldi \\ Muller $^{1}$, Joandes Henrique Fonteque ${ }^{1}$
}

${ }^{1}$ Universidade do Estado de Santa Catarina, SC, Brazil. *Corresponding author: anderson.sji@hotmail.com

\begin{abstract}
The aim of this study was to evaluate the influence of seasons on the hematological profile in horses used for urban traction in the city of Lages, Brazil. Blood samples were collected of the twenty crossbreed horses used for urban traction in the city of Lages, Brazil, carried out in four different periods according to the seasons, for carrying out the hematological profile, plasma total protein (PTP) and plasma fibrinogen. PTP was determined by refractometry method and the determination of plasma fibrinogen by heat precipitation method. Climate variations, such as maximum and minimum temperature, relative humidity and rainfall index for each period were obtained through access to the Center of Environmental Resources Information and Hydrometeorology of Santa Catarina. All values found were within the reference values commonly used for equine specie. There was no significant difference throughout the seasons on the values of erythrogram, leukogram, neutrophil-lymphocyte ratio and PTP. The $\mathrm{MCH}$ and plasma fibrinogen were higher in summer and eosinophils had significantly higher values in winter followed by summer. The region of Lages presents marked seasonal fluctuations, and these have little influence on hematological characteristics in horses used for urban traction.
\end{abstract}

Keywords: Cart horse; equine; hemogram; seasons.

RESUMO: O objetivo deste estudo foi avaliar a influência das estações do ano sobre o perfil hematológico em cavalos utilizados para tração urbana na cidade de Lages, Brasil. Amostras de sangue foram coletadas de vinte equinos mestiços utilizados para tração urbana na cidade de Lages, Brasil, realizada em quatro períodos distintos de acordo com as estações do ano, para a realização do perfil hematológico, proteína plasmática total (PTP) e fibrinogênio plasma. PTP foi determinada pelo método de refractometria e a determinação de fibrinogênio plasmático pelo método de precipitação pelo calor. As variações climáticas, como temperatura mínima e máxima, umidade relativa do ar e índice de pluviosidade de cada período foram obtidas por meio de acesso ao Centro de informações de Recursos Ambientais e Hidrometeorologia de Santa Catarina. Todos os valores encontrados estiveram dentro dos valores de referência comumente usados para a espécie equina. Não houve diferença significativa ao longo das estações sobre os valores do eritrograma, leucograma, relação neutrófilo:linfócito e na proteína total plasmática. Os valores de hemoglobina globular média e fibrinogênio plasmático foram maiores no verão e os eosinófilos apresentaram valores significativamente maiores no inverno seguido do verão. A região dos Campos de Lages apresenta flutuações sazonais bem demarcadas, e estas apresentam pouca influência nas características hematológicas nos equinos utilizados para tração urbana.

Palavras-chave: Carroceiro; equino; estações; hemograma 


\section{INTRODUCTION}

The current literature brings information of different factors that can alter several physiological parameters in individuals, yet without having much clinicopathological validation for professionals (Paladino et al., 2014; Uluisik et al., 2013; Lacerda et al., 2006; Babeker et al., 2013). In hematology, such considerations are even more timely, once blood is a very dynamic tissue and its primary responsibility is the maintenance of body homeostasis in various conditions (Jain, 1993).

Horses show great exercise capacity and cardiorespiratory efficiency, requiring competent hematopoietic tissue to adapt to the different demands of work, either in natural or artificial conditions. This feature has great influence of factors inherent to the individual, especially genetic, clearly exposed in different breeds with different skills to work (McGowan, 2008).

Factors such as diet, level of training, reproductive status, age, sex, circadian variations, degree of excitement and general health also affect hematologic values (Santué et al., 2009; Uluisik et al., 2013), which can make hematologic evaluation challenging.

Several studies have sought to investigate the effect that seasonality could play in haematological characteristics in horses (Satué et al., 2011; Dmoch et al., 2008), donkeys (Zakari et al., 2015), tilapia (Jerônimo et al., 2011), cows (Casella et al., 2013), camels (Babeker et al., 2013), human athletes (Banfi et al., 2011), among others. The results of these studies were variable depending on the species and location, showing that the specificity is the most appropriate way for studies in this field.

The cart horses are a group somewhat unassisted by society in
Brazil, therefore, since the poor conditions of life that most of these animals have, they are susceptible to various diseases (Souza, 2006; Oliveira et al., 2007; Kadani et al., 2014). The 'Amigo do Carroceiro' Extension Program (PAC) of the Agroveterinary Science Center (CAV) of the State University of Santa Catarina (UDESC), through volunteer teaching and students of the Veterinary Medicine, seek to improve the living conditions and general health of cart horses (Fonteque et al., 2010; Schade et al., 2013).

The aim of this study was to evaluate the influence of seasons in hematological profile, total plasma protein and plasma fibrinogen in horses used for urban traction from Lages, SC, Brazil.

\section{MATERIAL AND METHODS}

Were used twenty crossbreed horses adults (sixteen males and four females), with estimated average age of $17.5 \pm 4.7$ years (Muylle, 2010). They were clinically healthy participants of the 'Amigo do Carroceiro' Extension Program (PAC) of the Agroveterinary Science Center (CAV) of the State University of Santa Catarina (UDESC). The animals were kept in semi extensive system, feed with natural pasture, mineral salt, commercial concentrated feed and water ad libitum. The weight of horses was estimated by tape correlation between body mass and chest circumference and body condition score was determined according Speirs (1999)

The hematologic profile was analyzed by means of the red blood cell count (RBC) and white blood cell count (WBC), packet cell volume (PCV), hemoglobin (HGB), mean corpuscular volume (MCV), mean corpuscular hemoglobin $(\mathrm{MCH})$, mean corpuscular hemoglobin concentration (MCHC), 
platelet count, differential leukocyte count, PTP and plasma fibrinogen in four different periods according to the seasons. The blood collection was performed in the following periods: Spring, from September 22 to December 20; Summer: from December 21 to March 19; Autumn, March 20 to June 19; Winter, from June 20 to September 21; between the years 2013 and 2014.

Blood samples was collected by venipuncture of the jugular in vacuum tubes with anticoagulant 10\% EDTA (K3 Hemogard, $4.0 \mathrm{~mL}$, Vacutainer Systems, Becton Dickinson, England). RBC and WBC was performed using the hemathocimetric method in a Neubauer chamber and manufactured blood smears stained with Panotic to the differential leukocyte count and estimated platelet held in optical microscopy. The PTP was determined by refractometry method (refractometer Attago Co.), and the determination of plasma fibrinogen by the heart precipitation method by the second heat Jain (1993). The PCV was determined by microhematocrit method, centrifugation $3500 \mathrm{rpm}$ for five minutes (Jain, 1993). The MCV, MCH and $\mathrm{MCHC}$ were calculated as described by Jain (1993). HGB was determined by colorimetric spectrophotometry in electronic equipment model Theratio Plate ${ }^{\circledR}$ Tp analyzer.

The study was conducted in the city of Lages in the state of Santa Catarina, Brazil, in the coordinates 274'ㄷ' $S$ and 5019'34" W, at an altitude of 884 meters (IBGE, 2014). Climate changes regarding minimum and maximum temperature, relative humidity and rainfall index for each period were obtained through access to the Center of Environmental Resources Information and Hydrometeorology of Santa Catarina (CIRAM/EPAGRI).

For statistical analysis it was applied the analysis of variance
(ANOVA) followed by Tukey test to compare variables between the four seasons, with $\mathrm{P}<0.05$ (CURI, 1998).

\section{RESULTS AND DISCUSSION}

The mean values and standard deviation of daily and cumulative rainfall, rainy days, relative humidity, minimum, maximum temperature and average summer seasons, autumn, winter and spring are shown in Table 1.

Table 1 - Mean and standard deviation ( $x \pm s d)$ daily and accumulated rainfall, rainy days, relative humidity, minimum, maximum and mean temperature during summer, autumn, winter and spring in the city of Lages, SC, Brazil, between the years 2013 and 2014. (Source: EPAGRI/CIRAM).

\begin{tabular}{lcccc}
\hline \multirow{2}{*}{ Variables (Units) } & \multicolumn{4}{c}{ - Season --- } \\
\cline { 2 - 5 } & Summer & Autumn & Winter & Spring \\
\hline Daily rainfall $(\mathrm{mm})$ & $5.55 \pm 10.71$ & $2.95 \pm 9.95$ & $7.01 \pm 16.61$ & $5.16 \pm 10.31$ \\
Accumulated rainfall $(\mathrm{mm})$ & 499.70 & 273.90 & 652.00 & 464.80 \\
Rainy days & 53.00 & 33.00 & 42.00 & 42.00 \\
Relative humidity $(\%)$ & $78.64 \pm 9.10$ & $84.41 \pm 14.53$ & $85.24 \pm 12.15$ & $79.94 \pm 8.83$ \\
Minimum Temperature $\left({ }^{\circ} \mathrm{C}\right)$ & $15.53 \pm 2.22$ & $9.37 \pm 4.02$ & $7.64 \pm 3.22$ & $11.61 \pm 3.10$ \\
Maximum temperature $\left({ }^{\circ} \mathrm{C}\right)$ & $27.55 \pm 3.56$ & $20.00 \pm 3.28$ & $17.89 \pm 5.19$ & $22.22 \pm 3.98$ \\
Average temperature $\left({ }^{\circ} \mathrm{C}\right)$ & $20.94 \pm 2.38$ & $14.01 \pm 2.87$ & $11.77 \pm 3.92$ & $16.44 \pm 2.95$ \\
\hline
\end{tabular}

The data is in line with the historically climatic characteristics known for the region (Monteiro, 2001). Summer presented with milder climate and considerable rainy, and the autumn had reduced rainy periods. In contrast, the winter was humid with lots of rainy periods and low temperatures, and several days with negative temperatures at dawn, with the occurrence of frost, frequent phenomena during this period. Spring presented with mild temperatures and reduced rainy periods.

Mean values and standard deviations for the RBC, PCV, HGB, $\mathrm{MCV}, \mathrm{MCH}, \mathrm{MCHC}$, platelet count, PTP, plasma fibrinogen, WBC, neutrophils, lymphocytes, monocytes, eosinophils, basophils, neutrophil-lymphocyte ratio and live weight of horses in the summer seasons, autumn, winter and spring are 
shown in Table 2.

Table 2 - Mean and standard deviation values ( $x \pm s d)$ of the RBC, PCV, HGB, MCV, MCHC, $\mathrm{MCH}$, platelet count (Plat.), PTP, fibrinogen (Fib.), WBC, neutrophils (Neut.), lymphocytes (lymp.), monocytes (Mon.), eosinophils (Eosin.), basophils (Bas.), neutrophil-lymphocyte ratio (N$\mathrm{L}$ ) and body weight (BW) of crossbred horses used for urban traction, in summer seasons, autumn, winter and spring between the years 2013 and 2014 in the city of Lages, SC, Brazil.

\begin{tabular}{|c|c|c|c|c|}
\hline \multirow{2}{*}{ Variable (Units) } & \multicolumn{4}{|c|}{- Season - } \\
\hline & Summer & Autumn & Winter & Spring \\
\hline $\operatorname{RBC}\left(x 10^{8 / \mu L}\right)$ & $6.74 \pm 0.63$ & $6.21 \pm 0.43$ & $6.54 \pm 0.77$ & $6.65 \pm 0.96$ \\
\hline PCV (\%) & $33.50 \pm 3.03$ & $32.11 \pm 2.49$ & $33.58 \pm 2.61$ & $33.42 \pm 3.55$ \\
\hline HGB (g/dL) & $11.72 \pm 1.03$ & $11.48 \pm 0.97$ & $11.73 \pm 1.08$ & $11.62 \pm 1.24$ \\
\hline $\operatorname{MCV}(\mathrm{fL})$ & $49.94 \pm 4.57$ & $51.73 \pm 3.10$ & $51.68+3.90$ & $50.71 \pm 5.16$ \\
\hline $\mathrm{MCHC}(\mathrm{g} / \mathrm{d})$ & $35.00 \pm 1.20$ & $35.78 \pm 1.65$ & $34.91 \pm 1.37$ & $34.83 \pm 1.75$ \\
\hline $\mathrm{MCH}(\mathrm{pg})$ & $23.14 \pm 5.51^{\mathrm{a}}$ & $18.48 \pm 1.12^{b}$ & $17.27 \pm 3.00^{b}$ & $17.69 \pm 2.27^{b}$ \\
\hline Plat. ( $\left.\times 10^{3 / \mu L}\right)$ & $189.67 \pm 59.83$ & $204.95 \pm 54.57$ & $221.94 \pm 53.06$ & $227.67 \pm 60.40$ \\
\hline PTP ( $g / d \mathrm{~L})$ & $7.48 \pm 0.48$ & $7.19 \pm 0.60$ & $7.28 \pm 0.58$ & $7.38 \pm 0.56$ \\
\hline Fib. (mg/dL) & $375.00 \pm 75.38^{\mathrm{a}}$ & $294.74 \pm 122.36^{b}$ & $294.74 \pm 91.13^{b}$ & $278.95 \pm 97.63^{b}$ \\
\hline WBC $\left(\times 10^{3 / \mu L}\right)$ & $8.71 \pm 1.56$ & $9.27 \pm 2.26$ & $9.64 \pm 3.93$ & $9.15 \pm 1.89$ \\
\hline Neut. $\left(x 10^{3 / \mu L}\right)$ & $5.17 \pm 1.54$ & $6.00 \pm 1.68$ & $5.67 \pm 2.55$ & $5.34 \pm 1.65$ \\
\hline Lymp. (x103//LL) & $2.52 \pm 0.55$ & $2.25 \pm 0.87$ & $2.64 \pm 1.45$ & $2.87 \pm 1.08$ \\
\hline Mon. $(/ \mu \mathrm{L})$ & $246.58 \pm 130.50$ & $406.21 \pm 291.96$ & $371.21 \pm 305.61$ & $291.21 \pm 178.82$ \\
\hline Eosin. $(/ \mu \mathrm{L})$ & $588.50 \pm 134.51^{\mathrm{ab}}$ & $517.47 \pm 343.37^{\circ}$ & $813.58 \pm 563.12^{\mathrm{a}}$ & $553.08 \pm 328.30^{\circ}$ \\
\hline Bas. (/ $/ \mu \mathrm{L})$ & $179.75 \pm 166.21$ & $100.74 \pm 109.44$ & $142.68 \pm 318.83$ & $95.34 \pm 101.82$ \\
\hline $\mathrm{N}-\mathrm{L}$ & $2.13 \pm 0.71$ & $3.10 \pm 1.54$ & $2.63 \pm 1.74$ & $2.21 \pm 1.36$ \\
\hline $\mathrm{BW}(\mathrm{kg})$ & $394.50 \pm 52.98$ & $389.05 \pm 53.58$ & $376.63 \pm 47.32$ & $377.68 \pm 47.31$ \\
\hline
\end{tabular}

For different letters there is no significant difference $(P<0.05)$ between seasons.

The average values for the hemogram, PTP and plasma fibrinogen found are within the reference range for the equine species (Jain, 1993). There was no significant difference $(P>0.05)$ throughout the seasons on the values of erythrogram, leukogram, neutrophillymphocyte ratio and PTP. The $\mathrm{MCH}$ and plasma fibrinogen were higher in summer and eosinophils was significantly greater in winter followed summer $(\mathrm{P}<0.05)$.

The greatest value of $\mathrm{MCH}$ found during summer seems to have little clinical significance, because it was expected that the remaining erythrocyte variables also accompanied the same trend, which did not occur. The literature is controversial at this point, as in studies of Arab mares and Thoroughbred, they found higher values of RBC, HGB and PCV in the autumn and winter, which was justified on the basis of metabolic acclimation to environmental conditions (Gill e Kompanowska-Jezierska, 1986).

Lower temperatures may induce elevation of metabolic capacity, stimulating erythropoiesis (Ruiz et al., 2004), associated with increased sympathetic activity in the winter, leading to increased mobilization of the spleen to release erythrocytes into the blood stream (Hata et al., 1982).

In contrast, Santué et al. (2013) reported that lower temperatures reduce the half-life of the erythrocytes, consequently reducing its overall score, as well as affecting other related variables. Similarly, higher temperatures, could in some way affect erythrocyte variables related to a decrease in body fluids due to the thermoregulatory mechanisms (Kolar et al., 1988). Such hypotheses have not been proven in this study, which may be explained by adaptation to working arrangements and management conditions, which show little variation between the owners of these animals.

The PT were similar throughout the experimental period $(P>0.05)$, contrary to the hypothesis that the lower availability of food in winter may cause a decrease, since the supply of the animals came from natural pasture which is also subject to the bad weather. The results of Santué et al. (2013) contradict this hypothesis by assessing the effect of seasonality in hematological profile of mares Carthusian arrays and finding smaller PTP in summer, even on best quality forage.

The effect that seasonality can have on WBC count is attributed, among other factors to the stress associated with the cold in winter, leading to suppression of the immune response (Apanius, 1998). In contrast, another study shows that during winter the WBC can have an increase, because the lymphoid organs tend to become larger in colder seasons (Nelson e Demas, 1996). 
In this study, only the number of eosinophils had significant difference $(\mathrm{P}<0.05)$, presenting higher in winter. Eosinophil functions are not well determined, however, there is evidence that these cells can respond to attacks mucous membranes and provide defense mechanisms against larval stages in the phases of the parasitic infestation. They are also involved in modulating the allergic response and the immune reactions (Weiser, 2012). Santué et al. (2013) found higher eosinophil values in the spring, the same period that commonly observed higher concentrations of parasites on pastures.

While there is no statistical difference, the weight of the animals tended to be higher in the summer with a decrease in winter. This effect was not expressed clinically, in terms of the significant reduction of body weight, since the animals were not totally dependent on the natural availability of food, as given regular commercial diet and mineral supplementation throughout the study period, therefore, during the winter, period of increased scarcity of pasture, the impact by dietary restriction was reduced.

\section{CONCLUSION}

The region of Lages with well marked seasonal fluctuations, have little influence on hematological characteristics in cart horses, and the interpretation of the hemogram for this class of animals show little fluctuation during the year.

\section{INFORMATIVE NOTES}

The animal use met the requirements of the Santa Catarina State University, Animal Ethics Committee ( $n^{\circ}$ 01.06.12). Animal owners gave consent for their inclusion in the study.

\section{REFERENCES}

APANIUS, V. Stress and immune response. In: MØLLER, A.P.; MILINSKI, M.; SLATER, P.J.B. Stress and behavir. New York: Academic Press, 1998, p.133-153.

BABEKER, E.A.; ELMANSOURY, Y.H.A.; SULEEM, A.E. The influence of season on blood constituents of dromedary camel (Camelus dromedaries). Online Journal Animal Feed Research, v.3, p.1-8, 2013.

BANFI, G.; LUNDBY, C.; ROBACH, P.; LIPPI, G. Seasonal variations of haematological parameters in athletes. European Journal of Applied Physiology, v.111, n.1, p.9-16, 2011.

CASELLA, S.; SCIANÒ, S.; ZUMBO, A. Effect of seasonal variations in Mediterranean area on haematological profile in dairy cow. Comparative Clinical Pathology, v.22, n.4, p.691695, 2013.

CURI, P.R. Metodologia e Análise da Pesquisa em Ciências Biológicas. Botucatu: Tipomic, 1998, 263p.

DMOCH, M.; POLONIS, A.; SABA, L. Influence of seasons on the haematological and biochemical parameters of blood in horses. Medycyna Weterynaryjna, v.64, p.930933, 2008.

FONTEQUE, J.H.; PAOLINI, E.; SILVA, M.C. Projeto amigo do carroceiro. UDESC em Ação, v.1, n.4, p.1-8, 2010.

GILL, J.; KOMPANOWSKAJEZIERSKA, E. Seasonal changes in the red blood cell indices in Arabian brood mares and their foals. Comparative Biochemistry and Physiology - Part A: Molecular \& Integrative Physiology, v.83, p.643-51, 1986. 
HATA, T.; OGIHARA, T.; MARUYAMA, A. et al. The seasonal variation of blood pressure in patients with essential hypertension. Clinical and Experimental Hypertension, v.4, p.341-54, 1982.

INSTITUTO BRASILEIRO DE GEOGRAFIA E ESTATÍSTICA, IBGE. Cidades. Disponível em: <http://cod.ibge.gov.br/233OG>, 2014. Acessado em: 10 jan. 2016.

JAIN, N.C. Essentials of veterinary hematology. Philadelphia: Lea \& Febiger, 1993. 417p.

JERÔNIMO, G.T.; LAFFITTE, L.V.; SPECK, G.M.; MARTINS, M.L. Seasonal influence on the hematological parameters in cultured Nile tilapia from southern Brazilian Journal of Biology, v.71, n.3, p.719-725, 2011.

KADANI, M.Y.; DÓRIA, R.G.S.; GAMEIRO, A.H. Perfil dos carroceiros, avaliação clínica e do bem-estar dos seus cavalos de tração da região de Pirassununga-SP. Revista de Educação Continuada em Medicina Veterinária e Zootecnia, v.12, n.3, p.611. 2014.

KOLAR, J.; BHATNAGAR, S.K.; HUDAK, A.; SMID, J.; AL-YUSUF, A.R. The effect of a hot dry climate on the haemorrheology of healthy males and patients with acute myocardial infarction. American Journal of Tropical Medicine and Hygiene, v.91, n.2, p.7782, 1988.

LACERDA, L.; CAMPOS, R.; SPERB, $M$. et al. Haematologic and biochemical parameters in three high performance horse breeds from Southern Brazil. Archives of Veterinary Sciences, v.11, n.2, p.40-43, 2006.

MCGOWAN, C. Clinical pathology in the racing horse: the role of clinical pathology in assessing fitness and performance in the racehorse. Veterinary Clinics of North America:
Equine Practice, v.24, n.2, p.405-421, 2008.

MONTEIRO, M.A. Caracterização climática do estado de Santa Catarina: uma abordagem dos principais sistemas atmosféricos que atuam durante 0 ano. Geosul, v.16, n.31, p.69-78, 2001.

MUYLLE, S. Aging. In: EASLEY, J.; DIXON, P.M.; SCHUMACHER, J. Equine Dentistry. 3rd ed. Philadelphia: Elsevier Saunders, 2011. p.85-96.

NELSON, R.J.; DEMAS, G.E. Seasonal changes in immune function. Quarterly Review of Biology, v.71, n.4, p.511-48, 1996.

OLIVEIRA, L.M.; MARQUES, R.L.; NUNES, C.H.; CUNHA, A.M.O. Carroceiros e equídeos de tração: um problema sócio-ambiental. Caminhos da Geografia, v.8, n.24, p.204-216, 2007.

PADALINO, B.; RUBINO, G.; LACINIO, R.; PETAZZI F. Observations on the hematology of Standardbred horses in training and racing in Southern Italy. Journal Equine Veterinary Science, v.34, n.3, p.398-402, 2014.

RUIZ, G.; ROSENMANN, M.; CORTES, A. Thermal acclimation and seasonal variations of erythrocyte size in the Andean mouse Phyllotis xanthopygus rupestris. Comparative Biochemistry and Physiology - Part A: Molecular \& Integrative Physiolog., v.139, n.4, p.405-9, 2004.

SATUÉ, K.; BLANCO, O.; MUNOZ, A. Age-related differences in the haematological profile of Andalusian broodmares of Carthusian strain. Veterinarni Medicina, v. 54, ก. 4, p. 175-182, 2009.

SATUÉ, K.; GARDON, J.C.; MUNOZ A. Influence of the month of the year in the Hematological profile in carthusian broodmares. Hematology and Leukemia, v.1, p.1-6, 2013. 
SATUÉ, K.; MUÑOZ, A.; Zootecnia. v. 38. 2009.

MONTESINOS, P. Seasonal variations in the erythrogram in pregnant Carthusian mares. In: CONFERENCE OF THE EUROPEAN SOCIETY OF VETERINARY CLINICAL PATHOLOGY, 13., 2011, Dublin, Proceedings... Dublin: European Society of Veterinary Clinical Pathology, 2011. p. 65-73.

SCHADE, J.; BALDISSERA, R.; PAOLINI, E.; FONTEQUE, J.H. Biometria do equilíbrio podal em equinos de tração pertencentes ao Programa de Extensão "Amigo do Carroceiro" do Centro de Ciências Agroveterinárias da Universidade do Estado de Santa Catarina no município de Lages/SC, Brasil. Ciência Rural, v.43, n.3, p. 456-461, 2013.

SOUZA, M.F.A. Implicações para o bem-estar para equinos utilizados para tração de veículos. Revista Brasileira de Direito Animal, v.1, n.1, p. 51-52, 2006.

SPEIRS, V.C. Exame clínico de equinos. Porto Alegre: Artmed, 1999. 366p.

ULUISIK, D.; KESKIN, E.; OZAYDIN, T. Age and gender related changes in hematological parameters of thoroughbred foals. Biotechnic and Histochemistry, v.88, n.6, p.345-349, 2013.

ZAKARI, F.O.; AYO, J.O.; REKWOT, P.I.; KAWU, M.U. Effects of age and season on haematological parameters of donkeys during the rainy and cold-dry seasons. International Journal of Biometeorology, v.59, n.12, p.18131824, 2015.

WEISER, G. Introduction to Leukocytes and the Leukogram. In: THRALL, M.A.; WEISER, G.; ALLISON, R.; CAMPBELL, T.W. Veterinary hematology and clinical chemistry. 2nd ed. John Wiley \& Sons, 2012, p.118-122. 